\title{
Time and Location of Spawning of American Plaice in NAFO Divisions 3LNO
}

\author{
M. J. Morgan \\ Department of Fisheries and Oceans, P. O. Box 5667 \\ St. John's, Newfoundland, Canada A1C 5X1
}

\begin{abstract}
Spawning times and spawning locations of American plaice (Hippoglossoides platessoides) on the Grand Bank (NAFO Divisions 3LNO) were examined from 1971 to 1999. No specific spawning locations were identified, rather spawning was widespread throughout the Grand Bank. Spawning occurred over a broad seasonal period; spawning females were found in all months from February through August, with the highest proportion of spawners occurring in April through June. Significant annual variability occurred in the time of spawning, with a trend towards later spawning in the early-1990s. Spawning time was positively correlated with temperature and depth, and negatively correlated with the weighted mean age of the spawning stock biomass.
\end{abstract}

Keywords: American plaice, depth, Grand Bank, spawning, temperature

\section{Introduction}

American plaice (Hippoglossoides platessoides), a flatfish species found throughout the northwest Atlantic from west Greenland in the north to the Gulf of Maine off the eastern United States, was historically the most abundant flatfish in the northwest Atlantic. The largest population in Canadian waters occurs on the Grand Bank off Newfoundland in Div. 3LNO (Bowering and Brodie, 1991). This stock has been commercially exploited since the 1960s, with annual catches ranging between 17000 tons and 94000 tons during 1960-93. Catches declined to 7400 tons in 1994 and the stock has been under a fishery moratorium since 1995 because of low abundance (Morgan et al., MS 2001).

Previous studies of American plaice on the Grand Bank have indicated that spawning occurs throughout the area and that the principal spawning time is in March-May, although fish in spawning condition have been found from January to September (Maddock and Burton, 1999; Nevinsky and Serebryakov, 1973; Pitt, 1966; Zamarro, 1992). Spawning time in Div. 3NO may be later or at least continue longer than in Div. 3L (Nevinsky and Serebryakov, 1973). Apart from the study by Pitt (1966), which compared two years of spawning in St. Mary's Bay in southern Div. 3L, annual variability in spawning time of American plaice on the Grand Bank has not been investigated.
The population size of American plaice on the Grand Bank precipitously declined during the late1980 s to early-1990s and stock biomass is presently only about $10 \%$ of the levels in the mid 1970s-early 1980s (Morgan et al., MS 2001). Prior to 1990 the bulk of the population was found in Div. $3 \mathrm{~L}$ but subsequently most of the population has been in Div. 3 NO. During the past decade, the stock has moved to deeper, warmer waters (Iglesias et al., 1996; Morgan et. al., MS 1997; Morgan and Colbourne, 1999) concomitant with an extended period of below normal bottom temperatures (Colbourne et al., 1997).

This paper re-examines the spawning time and location of American plaice in Div. 3LNO using research survey data collected from 1971 to 1999. Given the large changes that have occurred in distribution and abundance of the stock, the data were also examined for changes and/or trends in timing and location of spawning.

\section{Materials and Methods}

Data were obtained from Canadian research vessel surveys conducted from 1971 to 1999. Most of the data were from stratified random surveys (Doubleday, 1981). During the 29-year period, three gear and two vessel changes occurred (McCallum and Walsh, MS 1996). Only sets without gear damage were used and all sets were standardized to the prescribed distance 
used for the survey gear. No attempt was made to convert the data to a single standardized gear type. However, this should not affect maps of spawning location or estimates of spawning time. The number of survey sets by month and Division is given in Table 1.

Fish were assigned to maturity categories (Templeman et al., 1978) after visual examination of the gonads. Only data from female fish were analysed. Fish possessing hydrated eggs were considered to be in spawning condition (MatBP, MatCP, Partly Spent: see Table 2) as hydrated eggs are shed within a few days at most (Kjesbu et al., 1990). Spent fish were those thought to have completed spawning in the present year but had not yet begun to develop eggs for the following year (Spent P). Fish with opaque eggs but lacking clear eggs (MatAP) were not considered to be in spawning condition. American plaice are batch spawners (Maddock and Burton,
1999) and some fish in the MatAP category may have released a few egg batches and therefore been in spawning condition. However, these fish could not be visually distinguished from those that had not yet begun to spawn. Hence, as all fish in the MatAP category were considered to be non-spawners, the number of spawners is underestimated by an unknown quantity.

\section{Spawning location}

Only data from the spring (April to early July) surveys were used. Maturity data came from two sources: (a) samples collected for age determination (AAG); and (b) samples collected for length, sex and maturity (LSM) determination. LSM samples were collected on every set in which American plaice were caught, while AAG samples were collected in an ad hoc manner so that a prescribed number of otoliths were obtained per length group per Division. While the LSM samples are probably more representative of

TABLE 1. Number of sets, by Division and month, in Canadian research vessel surveys, 1971-99 combined.

\begin{tabular}{lrrrrrrrrrrrrr}
\hline \hline Div. & Jan & Feb & Mar & Apr & May & Jun & Jul & Aug & Sep & Oct & Nov & Dec & Total \\
\hline 3L & 619 & 710 & 393 & 883 & 3365 & 2287 & 982 & 1349 & 1025 & 1800 & 2549 & 563 & 16525 \\
$3 \mathrm{~N}$ & 49 & 159 & 387 & 424 & 1653 & 851 & 683 & 1437 & 685 & 594 & 583 & 173 & 7678 \\
$3 \mathrm{O}$ & 27 & 159 & 443 & 1111 & 1010 & 1131 & 351 & 668 & 523 & 584 & 303 & 81 & 6391 \\
Total & 695 & 1028 & 1223 & 2418 & 6028 & 4269 & 2016 & 3454 & 2233 & 2978 & 3435 & 817 & 30594 \\
\hline
\end{tabular}

TABLE 2. Description of female maturity stages used in this study. Adapted from Templeman et al. (1978).

Immature: Ovary small, grey to pink in colour; membrane thin and translucent; eggs not visible to the naked eye.

Spent L: Ovary thick-walled with no new eggs visible to the naked eye; spent in the previous (L-last) year.

Mat A-P: Eggs visible to naked eye in ovary itself; all eggs opaque; maturing to spawn in present year.

Mat B-P: Opaque and clear eggs present with less than $50 \%$ of the volume being clear eggs; spawning in the present (P) year.

Mat C-P: $50 \%$ or more of the volume are clear eggs; this stage also includes the ripe condition where the ovarian content is almost liquid with clear eggs; spawning in the present $(\mathrm{P})$ year.

Partly Spent P: Ovary not full as in Mat C-P; some eggs extruded but many clear eggs remaining.

Spent P: Spawning completed in present year but possibly a few clear eggs remaining; no new opaque eggs visible to the naked eye.

Spent P Mat N: Spawning completed in present year, and new opaque eggs, for spawning in the next (N) year, visible to the naked eye; this stage becomes Mat A-P in January of the next year.

Mat A-N: No evidence of previous spawning; but new opaque eggs, for spawning in the next (N) year, visible to the naked eye; this stage becomes Mat A-P in January of the next year. 
the location of spawning fish, these samples have only been collected since 1988. The AAG samples, however, were considered to be sufficient to identify spawning concentrations and any large changes in spawning location over time. Using the AAG data, the proportion of fish at length in each maturity category was calculated. In each set, the number of fish in each maturity category was derived by multiplying the proportion at length in each maturity stage (as determined from the AAG data) by the frequency of fish at each length in that set. Expanding symbol plots of the number of spawning fish in each set in each year from 1971 to 1999 were created using ACON data visualisation software made available by G. Black, Marine Fish Division, Bedford Institute of Oceanography, Dartmouth, Nova Scotia, Canada. To confirm the patterns found using the AAG data, similar plots were created using the LSM data for each year from 1988 to 1999 .

\section{Spawning time}

Annual spawning times of American plaice were determined using the AAG samples from all months. The average proportion of adult female fish that were maturing (MatAP, Spent P Mat N, MatAN), spawning (MatBP, MatCP, Partly Spent) and spent (SpentP) was calculated for each month for all years combined to determine an aggregate intra-annual pattern in spawning time.

Generalised linear models with logit link function and binomial error were used to determine the proportion of fish spent on each day, and to determine the day of the year on which $50 \%$ of the fish were spent. Aggregate analyses (1971-99) were conducted on the combined samples from Div. $3 \mathrm{LNO}$ and on the samples by Division. Annual analyses were also conducted on the combined samples from Divs. 3LNO. In generalized linear modelling, a link function describes how the expected value is related to the linear predictor $\eta$ (McCullagh and Nelder, 1983). For the logit link function

$$
\begin{gathered}
\eta=\log \left(\frac{\mu}{1-\mu}\right) \\
\text { and } \eta^{-1}\left(\frac{1}{1+\exp (-x)}\right)=\text { proportion spent }
\end{gathered}
$$

$$
\text { where } \begin{aligned}
x & =\tau+\gamma \mathrm{D} \\
\tau & =\text { intercept } \\
\gamma & =\text { day effect } \\
\mathrm{D} & =\text { Day of the year }
\end{aligned}
$$

A class variable was added to the model to test for Divisional differences and for year effects. The proportion spent was calculated as the number of spent fish divided by the sum of those fish maturing to spawn in the present year (MatAP), spawning and spent.

Average depth and average temperature occupied by the population during the spring survey was calculated by weighting the temperature and depth for each set by both fish abundance and total stratum area (Perry and Smith, 1994). Although these average values will not necessarily reflect the temperatures and depths during gonad maturation, they should reveal any temporal changes in the depth/temperature distribution of the American plaice population. Mean age of the spawning stock biomass (SSB) was calculated by weighting the age distribution in the spawning stock by the proportion of SSB biomass at age (as determined from sequential population analyses: Morgan et al., MS 1999). Average depth, temperature, and weighted mean age of the SSB were then tested for correlation with the day at which $50 \%$ of the fish were spent in each year (Zar, 1984).

\section{Results}

\section{Spawning location}

Spawning locations were similar from both the AAG and LSM analyses; as examples, distribution maps from selected spring surveys are presented in Fig. 1 (1975, 1980, 1985, 1990, 1996 and 1999) and Fig. 2 (1988, 1990, 1992, 1994, 1996 and 1999). Distribution patterns of spawning females show a high degree of correspondence in both data sets. In 1990, for example, both data sets indicate widespread spawning with concentrations of spawning fish in the northwestern portions of Div. $3 \mathrm{~L}$ and $3 \mathrm{O}$. Overall, the AAG and LSM analyses suggest that American plaice in Div. 3LNO do not have one specific spawning area, but spawn throughout the region. This feature is common to all years, with spawning always widespread. In recent years, the LSM data show more spawning in the southern portion of the range, as well as in deeper waters.

\section{Spawning time}

Females in spawning condition occurred in all months between February and August (Fig. 3). A few fish over the 29-year period have been found in spawning condition in November and December. Spawning appears to peak in April-June. Spent fish were present in all months, with the highest proportions in April to August. Fish maturing to 

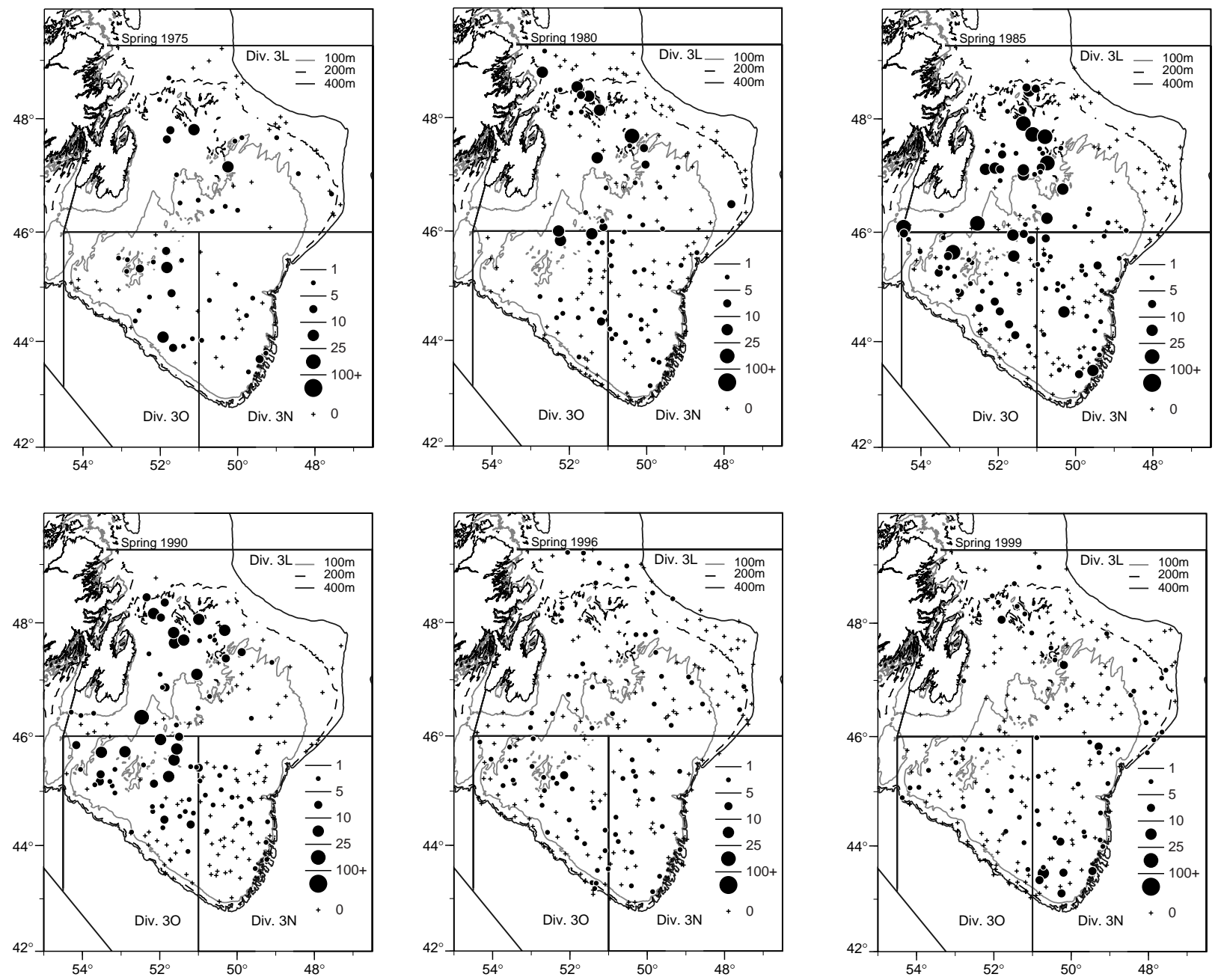

Fig. 1. Distribution of the number of female American plaice in spawning condition in Canadian spring surveys in NAFO Div. 3LNO. Data are from age and growth samples (AAG). Only selected years are shown.

spawn were also found in every month. Very high proportions of maturing fish were observed in September to December, indicating that maturation begins well in advance of the spawning season.

The generalized linear modelling results for all years and Divisions combined revealed that $50 \%$ of the females were spent by day 116 in April, with spawning occurring over a broad time window (Fig. 4). A significant difference in spawning time was detected among Divisions $\left(\chi^{2}=203, d f=2, p<0.0001\right)$ with fish in Div. $3 \mathrm{~N}$ and $3 \mathrm{O}$ spawning earlier (day 108 and 112 in April, respectively, for 50\% fish spent) than in Div. 3L (day 129 in May, for 50\% fish spent; Fig. 4).
Significant annual variability occurred in the day at which $50 \%$ of the females were spent $\left(\chi^{2}=993, d f\right.$ $=28, p<0.0001)$. Until 1990, the timing of this event was variable but exhibited little trend (Fig. 5). During the first half of the 1990s, however, the day at which $50 \%$ of the fish were spent became increasingly delayed (until late May-early June). Since then, spawning has been occurring slightly earlier in the year (i.e., in early May) although still later than in the pre-1990s period.

Between 1991 and 1995, the average depth occupied by the population increased sharply (from $120 \mathrm{~m}$ to nearly $220 \mathrm{~m}$ ) (Fig. 6). Subsequently, the average depth of the population has reverted to pre-1991 

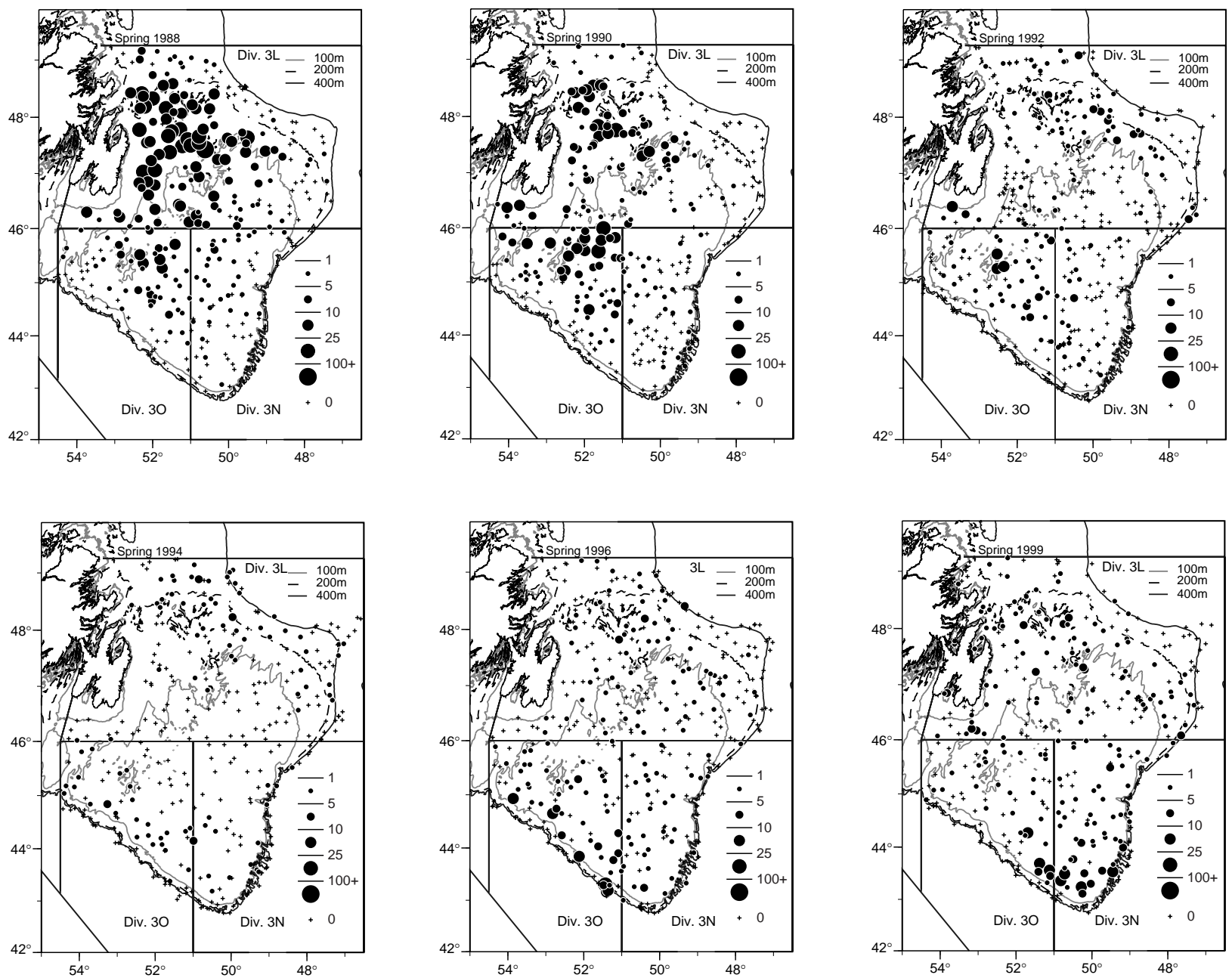

Fig. 2. Distribution of the number of female American plaice in spawning condition in Canadian spring surveys in NAFO Div. 3LNO. Data are from length, sex and maturity samples (LSM). Only selected years are shown.

values (Fig. 6). Average temperature occupied by the population also showed a large increase in the 1990s; since 1993, the stock has occurred at average water temperatures warmer than any previously observed. Weighted mean age of the SSB declined markedly between the early 1970s and 1995 (from age 12 to age 9), but has since slightly increased.

The day at which $50 \%$ of the females were spent was significantly correlated with (a) the average depth occupied by the population $(r=0.66, d f=28$, $p<0.0005$ ); (b) the average water temperature occupied by the population $(r=0.61, d f=28, p<0.001)$; and (c) the weighted mean age in the spawning stock $(r=$ $-0.62, d f=28, p<0.0005$ ) (Fig. 7). As average depth and temperature occupied by the stock increased and weighted mean age of the SSB decreased, spawning time became later. Both the depth and temperature correlations are driven by the data points in the 1990s.

\section{Discussion}

Spawning of American plaice is widespread on the Grand Bank with females in spawning condition occurring almost everywhere on the Bank. This is consistent with early studies, which also found spawning to be geographically extensive and without specific spawning 'grounds' (Nevinsky and Serbryakov, 1973; Pitt, 1966). There has been little interannual change in this pattern except that in recent years spawning has occurred in deeper water and spawning females have been more abundant in Div. $3 \mathrm{~N}$ and $3 \mathrm{O}$ than in Div. $3 \mathrm{~L}$. These changes reflect changes in stock distribution that commenced in the early-1990s. 

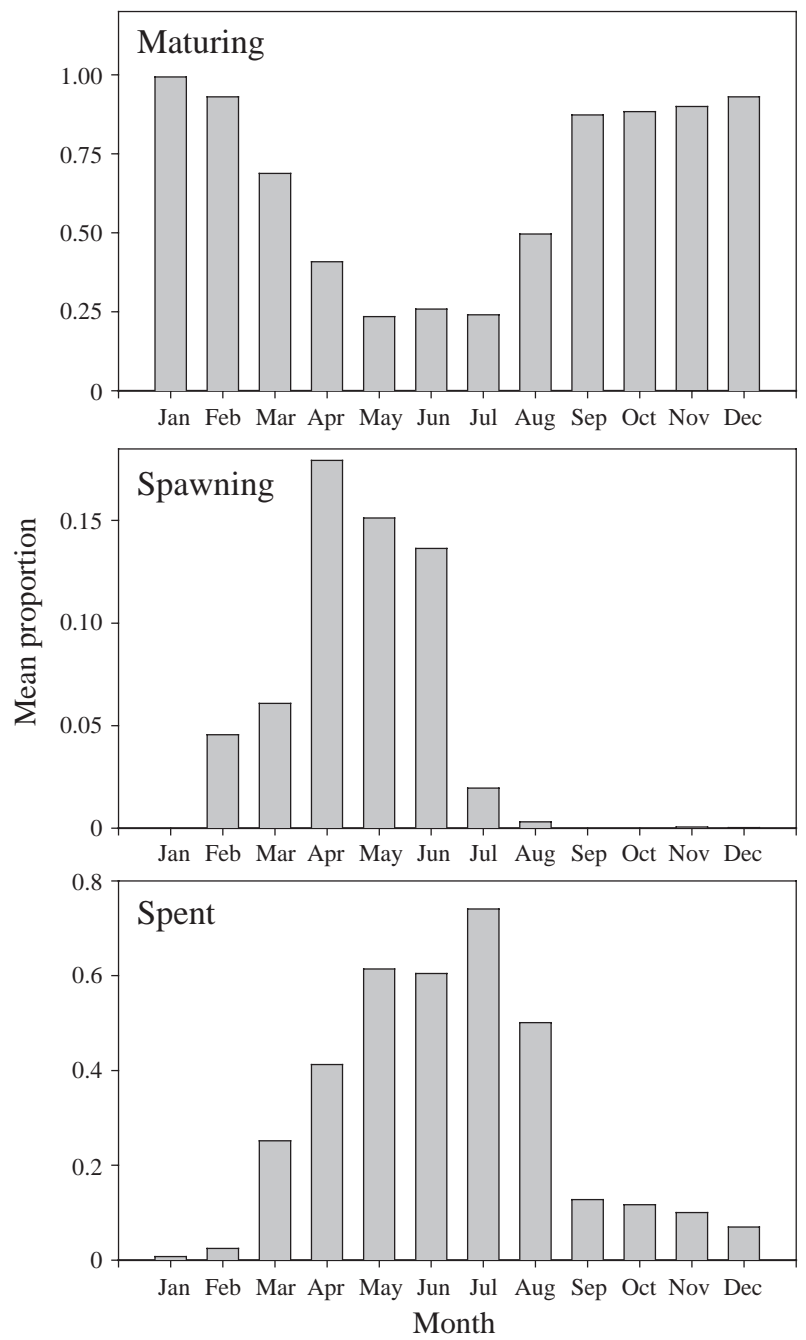

Fig. 3. Mean proportion of female American plaice maturing to spawn, in spawning condition, and spent in each month in NAFO Div. $3 \mathrm{LNO}$.

For Div. 3LNO combined, the day at which $50 \%$ of the spawning females were spent was day 116 in late April, a result consistent with previous studies (Nevinsky and Serbryakov, 1973; Pitt, 1966; Zamarro, 1992). Overall, American plaice in Div. $3 \mathrm{~N}$ and $3 \mathrm{O}$ spawned slightly earlier than those in Div. $3 \mathrm{~L}$. However, there was significant annual variation in the time of spawning with a trend towards later spawning in the 1990s.

Between 1971 and 1995, the weighted mean age of female spawners declined from 12 years old to 9 years old (Fig. 6). The greatest change occurred between 1990 and 1995 (when the average age
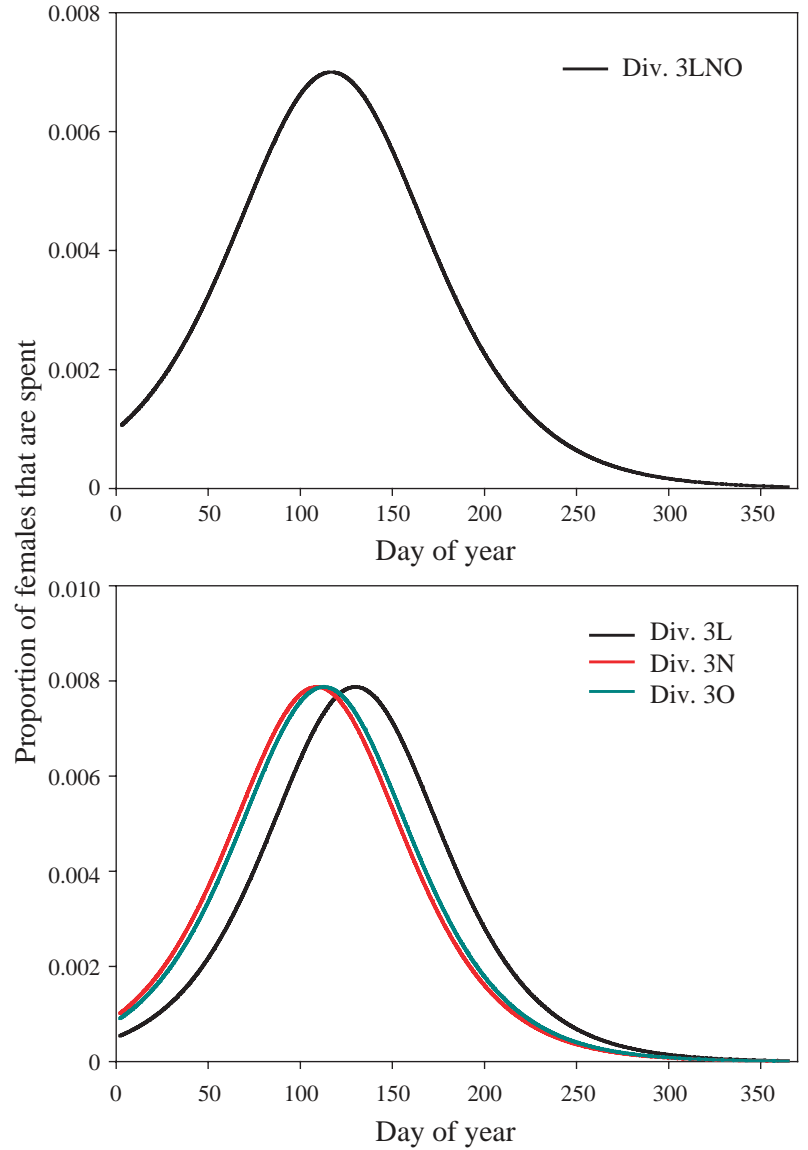

Fig. 4. Estimated proportion of female American plaice that were spent, by day of the year, for Div. $3 \mathrm{LNO}$ combined and separately by Division.

declined by two years) coincident with a 40-50 day shift in the timing of spawning time (Fig. 5). This suggests that younger plaice spawn later than older fish. A relationship between age and spawning time has been documented for cod (Gadus morhua), but in the opposite direction from American plaice with older fish spawning later than younger fish (Hutchings and Myers, 1993; Trippel and Morgan, 1994). Pitt (1966) found some indication of smaller fish spawning later than larger fish for American plaice.

Temperature influences the spawning time of marine fishes, with low temperatures often resulting in delayed spawning (Carscadden et al., 1997, Hutchings and Myers, 1994). However, during the early-1990s when the Div. 3LNO American plaice stock occupied warmer waters, spawning occurred later in the year than prior to 1990 when the stock occupied cooler waters. Although it is possible that 


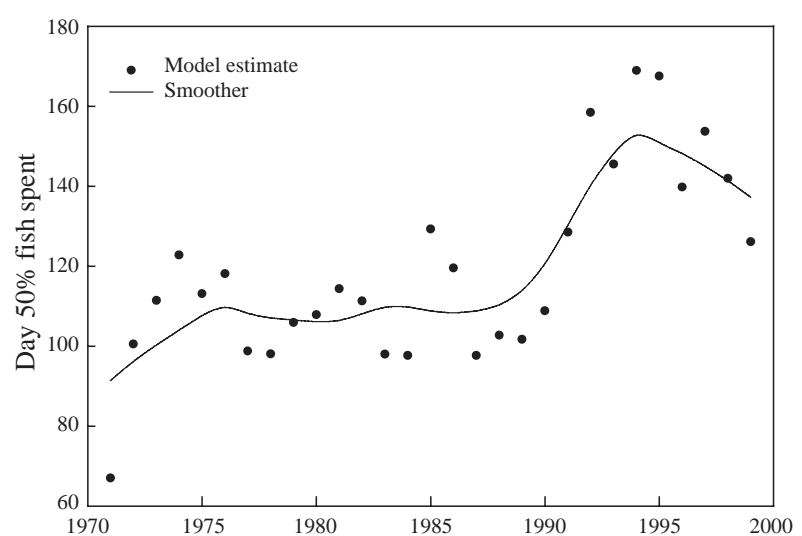

Fig. 5. Estimated day at which $50 \%$ of the female American plaice in Div. 3LNO were spent, 1971-99. A LOWESS smoother illustrates the trend.

the distribution of fish observed in the spring surveys may not be representative of the average conditions for the population over the year, it is more probable that the delay in spawning was related to the significant change in the depth distribution of the population (Iglesias et al., 1996; Morgan et al., MS 1999) (see also Fig. 6a) as well the dominance of younger age groups in the spawning stock. Pitt (1966) reported that, within the same spawning season, American plaice in deeper water spawn later than fish in shallower water and suggested that spawning time was affected by light intensity. Since light intensities are generally reduced in deeper waters (Angel, 1997), it is possible that the photoperiod cues regulating spawning (Peter, 1983) became dampened (or delayed) when the stock distribution shifted to greater depths, and therefore initiated spawning later.

Although widespread spawning of American plaice was a common feature throughout the 29-year survey time series, the time of spawning exhibited significant annual variability. This variation in timing has implications for possible spawning season closures for fisheries management purposes. Such closures would either have to be of sufficient length to encompass the observed range of annual variability or, alternatively, the timing of spawning monitored such that the timing and duration of seasonal closures would be adjusted as changes occurred in spawning time.
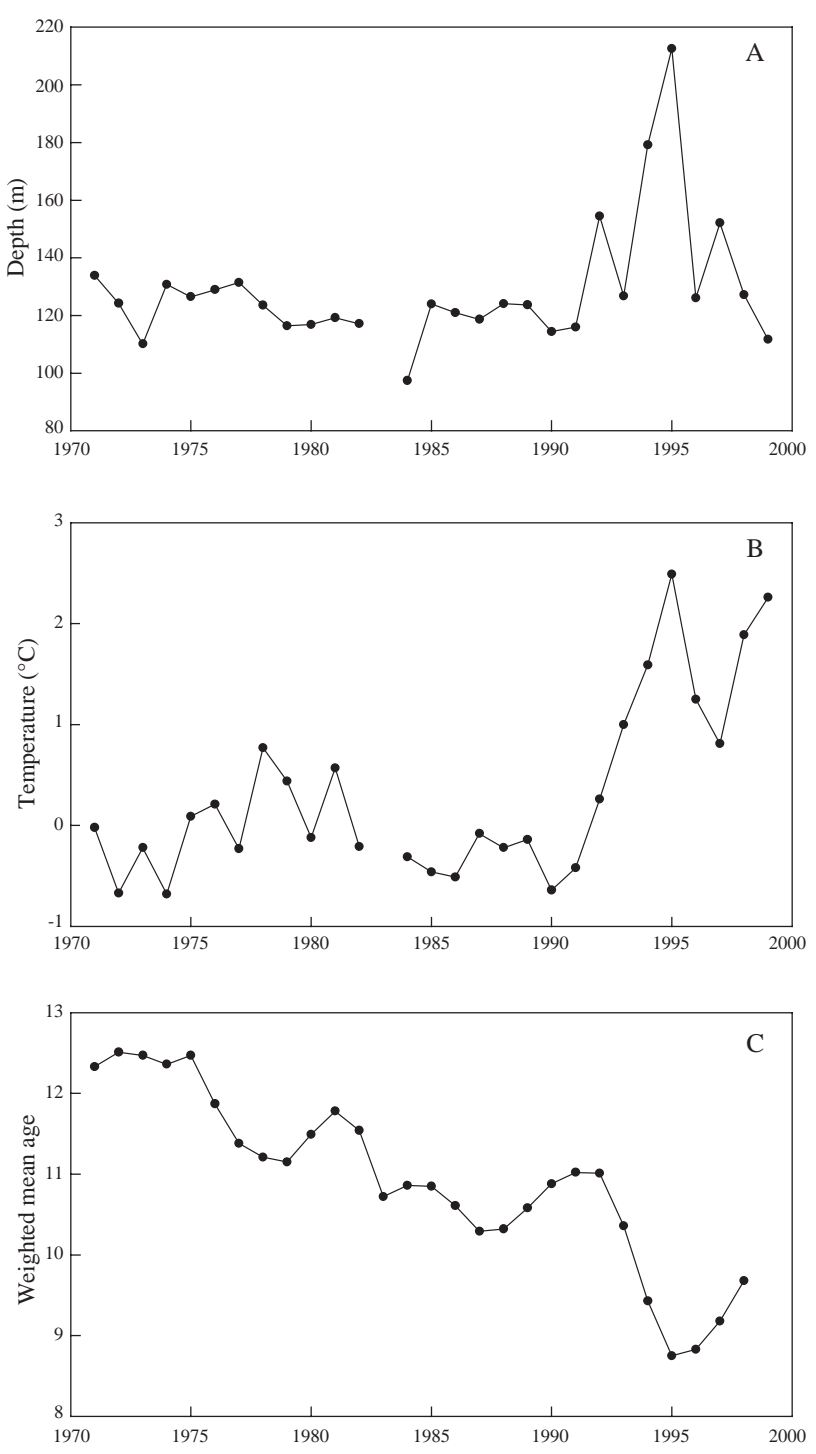

Fig. 6. Average depth (m) occupied by the population (A), average temperature $\left({ }^{\circ} \mathrm{C}\right)$ occupied by the population (B), and weighted mean age of the spawning stock biomass (C) for Div. 3LNO American plaice during Canadian spring surveys, 1971-99.

\section{Acknowledgements}

I thank the many technical staff and ships crew involved in the collection of the data used in this study. D. Parsons and M. O'Connell provided helpful comments on an earlier version of the manuscript. I also thank the editor F. Serchuk for his help in improving this manuscript. 

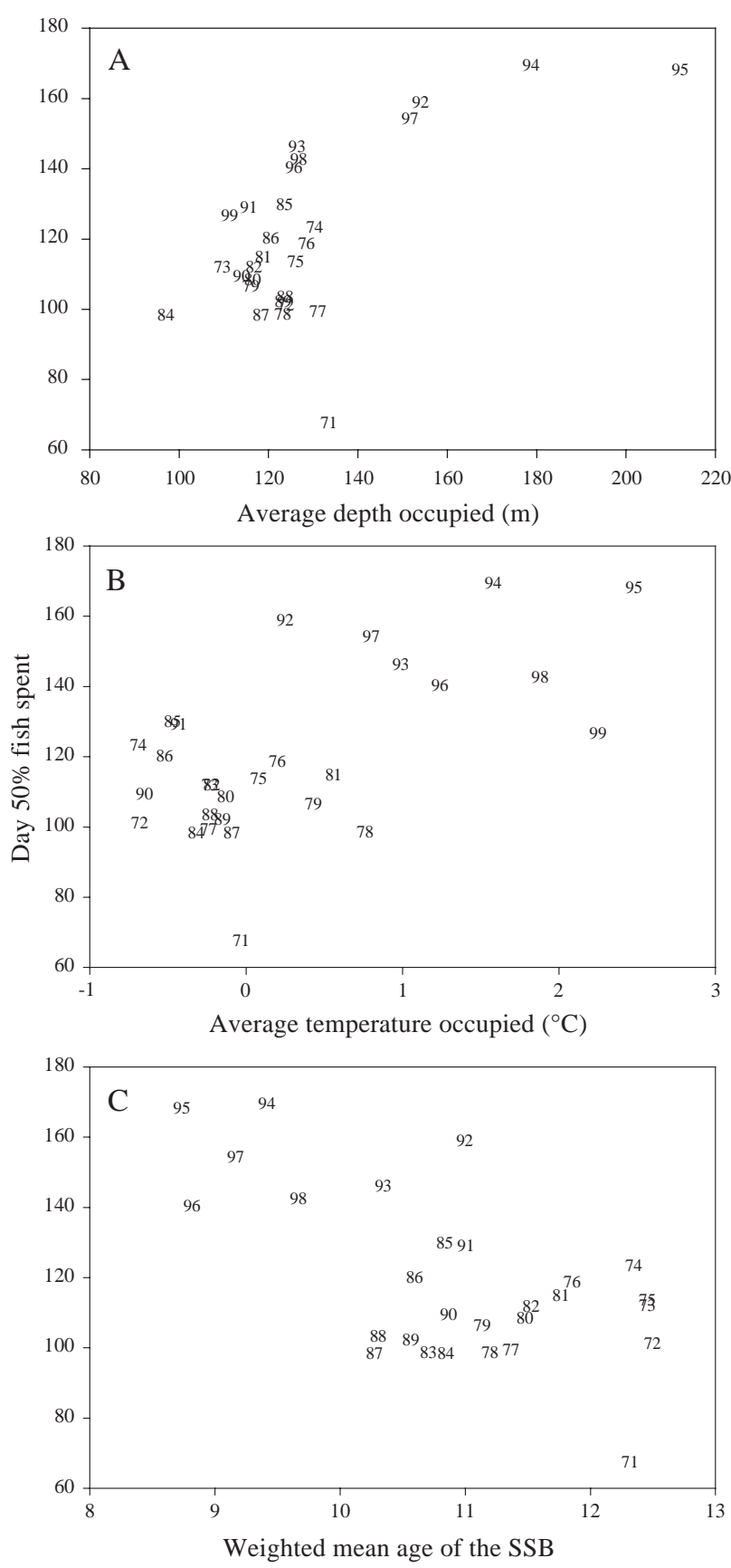

Fig. 7. Estimated day at which $50 \%$ of the female American plaice in Div. 3LNO were spent $v s$ average depth (m) occupied by the population (A), average temperature $\left({ }^{\circ} \mathrm{C}\right)$ occupied by the population $(\mathbf{B})$ and weighted mean age of the spawning stock biomass (C) during 1971-99. The symbols for the data points represent the year.

\section{References}

ANGEL, M. V. 1997. What is the deep sea? In: Deep-Sea Fishes. D. J. Randall and A. P. Farrell (eds.), Fish Phys.,
16: $1-40$

BOWERING, W. R., and W. B. BRODIE. 1991. Distribution of commercial flatfishes in the Newfoundland-Labrador region of the Canadian Northwest Atlantic and changes in certain biological parameters since exploitation. Neth. J. Sea Res., 27: 407-422.

CARSCADDEN, J., B. S. NAKASHIMA, and K. T. FRANK. 1997. Effects of fish length and temperature on the timing of peak spawning in capelin (Mallotus villosus). Can.J. Fish. Aquat. Sci., 54: 781-787.

COLBOURNE, E., B. DEYOUNG, S. NARAYANAN, and J. HELBIG. 1997. Comparison of hydrography and circulation on the Newfoundland shelf during 1990-93 with the long-term mean. Can. J. Fish. Aquat. Sci., 54 (Suppl. 1): 68-80.

DOUBLEDAY, W. G. 1981. Manual on groundfish surveys in the northwest Atlantic. NAFO Sci. Coun. Studies, 2: $55 \mathrm{p}$.

HUTCHINGS, J. A., and R. A. MYERS. 1993. Effect of age on the seasonality of maturation and spawning of Atlantic cod, Gadus morhua, in the Northwest Atlantic. Can. J. Fish. Aquat. Sci., 50: 2468-2474.

HUTCHINGS, J. A., and R. A. MYERS. 1994. Timing of cod reproduction: interannual variability and the influence of temperature. Mar. Ecol. Prog. Ser., 108: 21-31.

IGLESIAS, S., J. PAZ, and E. DE CARDENAS. 1996. Occurrence of American plaice (Hippoglossoides platessoides) at non-habitual depths in the northwest Atlantic, 1990-93. NAFO Sci. Coun. Studies, 24: 91-95.

KJESBU, O. S., P. R. WHITTHAMES, P. SOLEMDAL, and M. GREER WALKER. 1990. Ovulatory rhythm and a method to determine stage of spawning in Atlantic cod (Gadus morhua). Can. J. Fish. Aquat. Sci., 47: 11851193.

MADDOCK, D. M., and M. P. M. BURTON. 1999. Gross and histological observations of ovarian development and related condition changes in American plaice. J. Fish Biol., 53: 928-944.

MCCALLUM, B. R., and S. J. WALSH. MS 1996. Groundfish survey trawls used at the Northwest Atlantic Fisheries Centre, 1971-present. NAFO SCR Doc., No. 50, Serial No. N2726, 18 p.

MCCULLAGH, P., and J. A. NELDER. 1983. Generalized Linear Models. London, Chapman and Hall.

MORGAN, M. J. and E B. COLBOURNE. 1999. Variation in maturity-at-age and size in three populations of American plaice. ICES J. Mar. Sci., 56: 673-688.

MORGAN, M. J., W. B. BRODIE, and W. R. BOWERING. MS 1999. An assessment of American plaice in NAFO Divisions 3LNO. NAFO SCR Doc. No. 44, Serial No. N4099, $55 \mathrm{p}$.

MORGAN, M. J., W. B. BRODIE, B. P. HEALEY, D. MADDOCK PARSONS, D. STANSBURY, and D. POWER. MS 2001. An assessment of American plaice in NAFO Divisions 3LNO. NAFO SCR Doc. No. 59, Serial No. N4437, $70 \mathrm{p}$.

MORGAN, M. J., W. B. BRODIE, S. J. WALSH, and D. ORR. MS 1997. An assessment of Divisions 3LNO American plaice. NAFO SCR Doc. No. 60, Serial No. N2894, 47 p. 
NEVINSKY, M. M., and V. P. SEREBRYAKOV. 1973. American plaice, Hippoglossoides platessoides Fabr., spawning in the northwest Atlantic area. ICNAF Res. Bull., 10: 23-36.

PERRY, R. I., and S. J. SMITH. 1994. Identifying habitat associations of marine fishes using survey data: an application to the northwest Atlantic. Can. J. Fish. Aquat. Sci., 51: 589-602.

PETER, R. E. 1983. The brain and neurohormones in Teleost reproduction. In: Reproduction. Part A. Endocrine Tissues and Hormones. W. S. Hoar, D. J. Randall and E. M. Donaldson (eds), Fish Phys., 9: 97-135.

PITT, T. K. 1966. Sexual maturity and spawning of the American plaice, Hippoglossoides platessoides (Fabricius), from Newfoundland and Grand Bank areas.
J. Fish. Res. Board Canada, 23: 651-672.

TEMPLEMAN, W., V. M. HODDER, and R. WELLS. 1978. Sexual maturity and spawning in haddock, Melanogrammus aeglefinus, of the southern Grand Bank. ICNAF Res. Bull., 13: 53-65.

TRIPPEL, E. A., and M. J. MORGAN. 1994. Age-specific paternal influences on reproductive success of Atlantic cod (Gadus morhua L.) of the Grand Banks, Newfoundland. ICES Mar. Sci. Symp., 198: 414-422.

ZAMARRO, J. 1992. Determination of fecundity in American plaice (Hippoglossoides platessoides) and its variation from 1987 to 1989 on the tail of the Grand Bank. Neth. J. Sea Res., 29: 205-209.

ZAR, J. H. 1984. Biostatistical Analysis. Second Edition. Englewood Cliffs, New Jersey, Prentice-Hall Inc. 